\title{
Canada's System of Liability Coverage in the Event of Medical Harm: Is It Time for No-Fault Reform?
}

\section{Système canadien de couverture de responsabilité en cas de préjudice médical : le temps est-il venu de procéder à une réforme sans égard à la responsabilité?

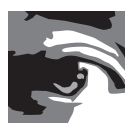

SHOO K. LEE, MBBS, FRCPC, PHD, DHC, OC

Professor of Paediatrics, Obstetrics and Gynecology

Professor of Public Health

University of Toronto

Director, MiCare Research Centre

Mount Sinai Hospital

Toronto, ON

BRIAN H. ROWE, MD, MSC, CCFP (EM), FCFP, FCCP, FCAHS

Professor

Department of Emergency Medicine and School of Public Health

University of Alberta

Edmonton, $A B$

COLLEEN M. FLOOD, LLM, SJD, FRSC, FCAHS

Professor and Research Chair, Health Law and Policy

Director, University of Ottawa Center for Health Law, Policy and Ethics

University of Ottawa

Ottawa, ON

SUKHY K. MAHL, MBA

Assistant Director

MiCare Research Centre

Mount Sinai Hospital

Toronto, ON 


\begin{abstract}
Many Canadians believe that physicians have malpractice insurance via the Canadian Medical Protective Association (CMPA). However, the CMPA is not an insurance company; it is a defence fund for physicians and has no obligation to compensate all claimants. CMPA expenses have increased nearly tenfold in 30 years and although public budgets support the majority of CMPA fees, less than $0.3 \%$ of injured patients receive compensation. A reform of the system is vital. Several developed countries have adopted a "no-fault" system to provide more equity and transparency and to ensure that the majority of funds go directly to injured patients rather than toward the payment of legal and administrative fees.
\end{abstract}

\title{
Résumé
}

De nombreux Canadiens croient que les médecins bénéficient d'une assurance contre la faute professionnelle par l'entremise de l'Association canadienne de protection médicale (ACPM). Cependant, l'ACPM n'est pas une compagnie d'assurances; il s'agit d'un fonds de défense pour les médecins et il n'y a aucune obligation d'indemniser tous les demandeurs. Les dépenses de l'ACPM ont presque décuplé en 30 ans. Et bien que les budgets publics soutiennent la majorité des frais de l'ACPM, moins de 0,3\% des patients blessés reçoivent une indemnisation. Une réforme du système est indispensable. Plusieurs pays développés ont adopté un système « sans égard à la responsabilité » pour offrir davantage d'équité et de transparence et pour garantir que la majorité des fonds aillent directement aux patients blessés plutôt quau paiement de frais juridiques et administratifs.

\section{Introduction}

Most physicians in Canada are members of the Canadian Medical Protective Association (CMPA) and believe that this provides them with malpractice insurance. But this is not the case: the CMPA is not an insurance company; their assistance to physicians is available strictly on a discretionary basis (Shannon v. Canadian Medical Protective Association 2016). The CMPA Council has full discretion to limit, decline or terminate assistance without reason. Essentially, neither does the CMPA provide a contract of indemnity for physicians, nor does it provide certainty of coverage for patients injured as a result of medical error. Regulatory colleges have voiced concern that the public may not be adequately protected and have stated there is a "tension between the coverage provided by the CMPA and the fact that there is no direct or legal obligation that the CMPA respond to claims" (Shannon v. Canadian Medical Protective Association 2016). Given that 95\% of Canadian physicians are CMPA members - a defence fund, not an insurance company - and that only a small fraction of injured patients ever receive compensation, is it time to reform medical malpractice insurance in Canada? 


\section{The Canadian Medical Malpractice System}

Health outcomes are affected by many factors, and even with the best medical care, unexpected adverse outcomes can occur. Baker et al. (2004) estimated that in Canada, 7.5\% of adult patients $(185,000$ per year) in acute care settings suffered a serious adverse event (AE), of which $37 \%$ were highly preventable and $20 \%$ of overall AEs resulted in death. Because psychiatric, obstetric, chronic care and long-term care patients were not examined, the number of incidents is likely much higher. In Canada, the only way for patients to seek compensation is through the courts.

Patients face an uphill battle in seeking compensation for injuries caused by medical error. First, they must pay the high cost of legal representation, which most cannot afford. Second, they also face the challenge of proving to a court that the physician failed to meet the general standard of care and that this failure was the cause of the harm they suffered (as opposed to, for example, a co-morbidity). The burden to establish the medical error is on the patient with whatever evidence she/he/they can furnish. Finally, the delays in court action mean that compensation, if awarded, will be delayed.

In order to ensure that injured patients are justly compensated and to protect physicians, the Colleges of Physicians and Surgeons in each province and territory require practising physicians to carry medical malpractice liability coverage or insurance. Most physicians believe that they are purchasing insurance through the CMPA; however, the CMPA declares itself as a "mutual defence" organization, meaning that they are not required to indemnify physicians, unlike an insurance company (Shannon v. Canadian Medical Protective Association 2016). The current system leaves "gaps" in coverage for physicians and, as this article describes, provides almost no coverage for patients injured as a result of medical error. The ideal system would ensure social justice, equity and transparency for both patients and physicians, wherein proving fault would not be a pre-requisite to accessing compensation for medical injuries. Making matters worse, the CMPA's membership premiums are heavily subsidized by the government, and the sustainability of the system is questionable.

\section{Is the current system sustainable?}

The CMPA annual reports between 1987 and 2017 showed that their membership nearly doubled from 50,261 in 1987 to 97,688 in 2017, while CMPA expenses (and consequently premiums) increased more than tenfold. While the largest CMPA expenses are damages paid to patients, the second largest expense is legal costs, which increased from $\$ 16$ million in 1988 to $\$ 168$ million in 2017 - an increase of 950\% (CMPA, personal communication, August 2018) (Figures 1 and 2). This increase in expenses is well beyond the inflationary rate of $87 \%$ for the same period. 
FIGURE 1. CMPA expenses from 1988 to 2017

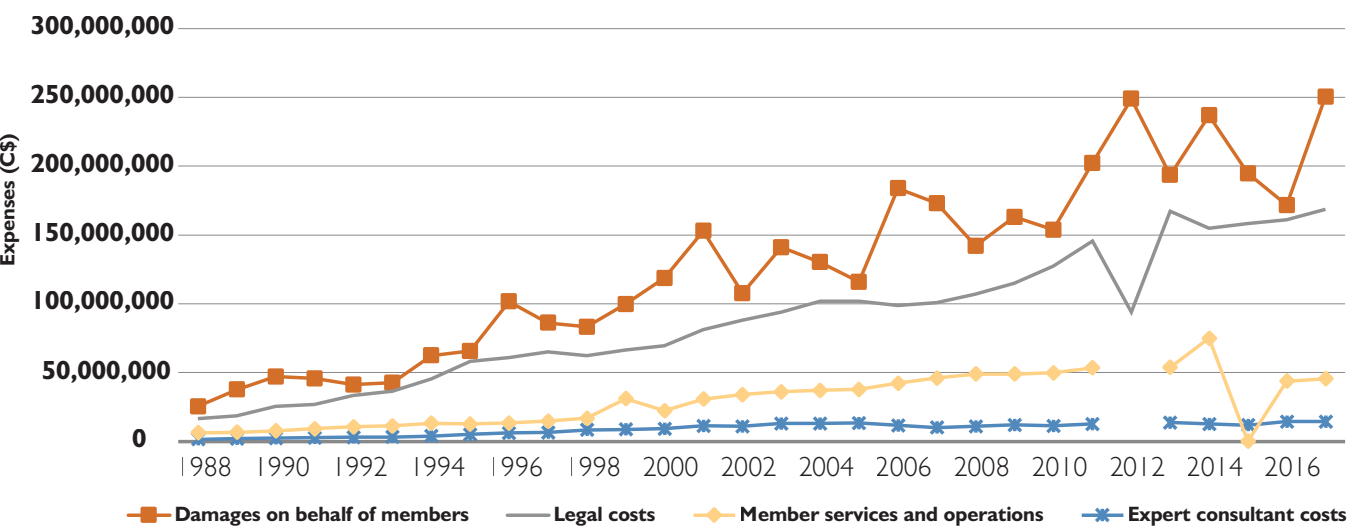

Across the board, CMPA expenses have increased significantly, raising questions about the sustainability of the system and how resources are allocated between payment of patient claims and the legal costs of defending those claims. Indeed, given that the majority of CMPA funding comes from the taxpayers, many believe that the majority of funds should be used to compensate injured patients rather than pay legal fees to defend against patient claims.

FIGURE 2. CMPA expenses in 2017

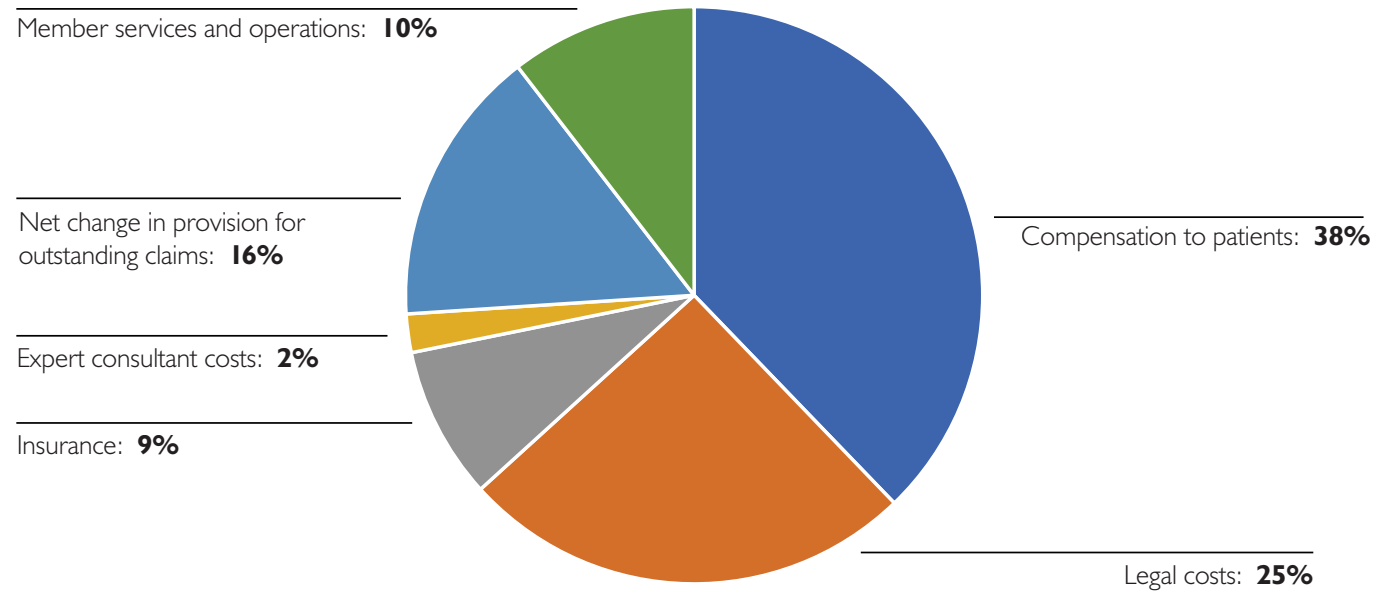

\section{Have the number of civil cases increased?}

A common misconception is that court actions against physicians have increased over time, which if true, would provide some explanation for the rising CMPA costs. However, CMPA records show that the number of cases commenced annually has changed negligibly and remains close to 900 per year since 1988 (CMPA, personal communication, August 2018). Given that membership has doubled over the last 30 years, this means that the number of 
cases commenced per capita has actually halved. A more recent estimate by Taylor (2013) than the one by Baker et al. (2004) approximates that 100,000 provider-error injuries occur per annum. With only 900 malpractice lawsuits brought forward each year $(0.9 \%$ of the 100,000 injuries), and a success rate at trial or settlement of only $38 \%$ (Nosheen and Culbert 2019), the percentage of cases compensated in which patients were harmed in avoidable error is an abysmal $0.34 \%$. Although $38 \%$ of all formal legal claims being compensated may appear to be a reasonable compensation rate, one must keep in mind that the number of cases brought forward represents less than $1 \%$ of all the medical injuries estimated to be occurring across Canada. Medical malpractice legal claims are brought forward so rarely, in part, due to the CMPA policies that deter injured patients from seeking compensation, such as mounting an aggressive defence or the prolonged nature of most litigation that few patients have the means to compete with (Gibson 2016). Furthermore, malpractice lawyers are less likely to take on cases in the first place due to the costs associated with litigation against such a well-financed defendant as the CMPA, tending only to accept cases with a high likelihood of success and a high payout (Nosheen and Culbert 2019). Some patients may not have the financial wherewithal to consider litigation; may be too sick to initiate a claim; may, in fact, not be aware of their right to sue; and/or may not be sure of how their injury was caused (as a fault of the physician or not). Unfortunately, many of those deterred by the strength and financial capacity of the CMPA are those that are most likely in need, which raises questions of equity and justice.

\section{Inequity and social justice}

In 2004, the CMPA and the provinces struck a deal allowing CMPA premiums to be subsidized by taxpayer money. Since then, provinces have provided subsidies ranging from $80 \%$ to $100 \%$ of premiums for all physicians. In data published by the CBC, provincial governments (except Nunavut and Northwest Territories where data were unavailable) have allocated $\$ 1.85$ billion in payment to the CMPA from 2014/15 to 2017/18 (Nosheen and Culbert 2019). The result is that when an injured patient files a lawsuit against a physician, the taxpayer is funding one side of that legal dispute leaving the patient to single-handedly fund the other side. The CMPA is known to have considerable resources and uses its financial capacity to robustly defend claims and avoid paying compensation to patients (Gibson 2016). An Ontario superior court judge commented in a ruling that the CMPA-funded lawyers in a court case had pursued a "scorched earth policy," challenging the plaintiff on every aspect of his case and making the trial unnecessarily lengthy (Gibson 2016: 313). Consequently, the current system creates major barriers to justice for patients who are harmed and discourages them from pursuing legal remedies or financial compensation. Hence, the question of equity and social justice must be raised. If the CMPA exists to protect physicians and does not compensate the majority of the public who suffer from medical error or injury, why is the public paying the costs? Arguably, the funding being devoted to the CMPA would be more efficiently utilized if redirected to injured patients rather than being consumed by legal and administrative costs. 


\section{Is everyone satisfied with the status quo?}

Criticisms regarding the system abound from all sides. Patients feel that the system takes too long to compensate the injured and costs taxpayers too much (Nosheen and Culbert 2019). There have also been repeated calls for system reform from various levels of government, resulting in numerous recommendations and reports (Gilmour 2006; Goudge 2017; Prichard and Robert 1990). In the 1997 and 2000 Ontario Physician Services Agreements, the Ministry of Health and the Ontario Medical Association agreed on the urgent need to examine all available alternatives for liability protection coverage (Ontario Ministry of Health and Long-Term Care 2016). Similar issues were discussed in the 2004, 2009 and 2012 Ontario Physician Services Agreements (Ontario Ministry of Health and Long-Term Care 2016). At the Canadian Medical Association's 2017 annual general council meeting, physicians themselves voted $79 \%$ in favour of a review of Canada's medical liability system and an exploration of other more affordable models for protecting patients and physicians (Collier 2017). Furthermore, in 2019, the Quebec College of Physicians released a statement calling for no-fault insurance for patients in order to guarantee compensation to victims of malpractice. They proposed a no-fault malpractice system similar to the province's no-fault automobile insurance (Gilmour and Luft 2019). Several developed countries have evolved to use a "nofault" malpractice system in an effort to provide a more equitable and transparent system for patients impacted by AEs.

\section{A No-Fault Compensation System}

A major no-fault scheme for compensation has existed in Canada for over 100 years in the form of Workers' Compensation and, likewise, the province of Quebec has had a no-fault compensation scheme for vaccine injuries since 1986. In the medical world, no-fault systems have existed in countries such as New Zealand and Sweden for over 40 years and in Finland, Norway and Denmark for over two decades (Studdert and Brennan 2001a). The United States operates state-based no-fault systems for specific injury types (Horwitz and Brennan 1995). In Canada, a no-fault system was used to compensate victims of the tainted blood scandal in the 1980s and '90s (Gilmour 2006). A no-fault system is able to compensate injured patients quickly and equitably while minimizing court time and legal costs. It also removes the requirement that compensation only be provided once blame has been assigned. In most countries that have adopted no-fault systems, physician malpractice is separately handled by regulators, as is the case for Sweden where complaints and disciplinary issues of medical providers are handled by the Medical Responsibility Board (World Bank 2013). Disciplinary action is kept entirely separate from the no-fault scheme.

In the current malpractice system, the majority of CMPA membership dues are paid by provinces using taxpayer money. In turn, only 38\% of CMPA expenses, or \$250 million of $\$ 662$ million in 2017, went to patients harmed while receiving medical care (CMPA, personal communication, August 2018). The intent behind funding medical malpractice coverage is to both protect physicians and compensate injured patients, but funds are skewed 
heavily to the former rather than the latter. A no-fault compensation system has the potential to compensate more patients than a tort-based system by vastly reducing legal fees, expert witness fees and much of the administrative costs.

\section{Are no-fault systems efficient and affordable?}

The administration of a no-fault system has been found to be highly cost-effective, although this may vary depending on implementation. It is instructive to consider the cost efficiencies achieved by comparative countries. Bismark and Paterson (2006) studied New Zealand's no-fault system and found administrative costs absorbed only $10 \%$ of total expenditures, with the remaining $90 \%$ available to compensate patients. Bovbjerg et al. (1997) found that Florida's no-fault system for newborns with severe birth-related neurological impairments incurred administrative costs of $10 \%$ compared with $47 \%$ under Florida's ordinary tort system for obstetrical cases, and awards were received more expeditiously in the former. Barringer (2006) reported similar findings, with administrative costs for the Florida and Virginia no-fault system ranging between $8 \%$ and 10\%. Sloan et al. (1998) also studied the Florida no-fault system and showed that families received a larger share of the money and paid less for lawyers' fees in the no-fault system. Similarly, the World Bank (2013) examined the medical malpractice systems in the US (tort) and Sweden (no-fault) and found that overhead administrative costs accounted for $60 \%$ of expenses in the US as compared to only $18 \%$ in Sweden.

Another concern with a change to a no-fault approach may be that liability and compensation costs would increase, given the increase in the number of claims; however, the evidence shows otherwise. Studdert et al. (1997) concluded that a no-fault system in Colorado or Utah could compensate four to six times more victims than the court system at the same cost as the existing tort system. One reason for these findings is that legal and administrative fees are greatly reduced in no-fault systems, allowing for a greater portion of premiums to go directly to claimants, as was found in a report comparing fault and no-fault systems internationally (Armstrong and Tess 2008). Furthermore, the report found that the total costs in fault versus no-fault systems are similar. It has been reported that the New Zealand no-fault system performs well at providing compensation; while awards are not as high as in the tort system, it is considered a fairer system and is similar to Canada's Workers' Compensation Board, with its ability to compensate far more people (Gibson 2016).

\section{Do defensive medicine costs play a role?}

Defensive medicine and no-fault systems are heavily debated issues on the national and international stage (Di Gregorio et al. 2015; Marchisio 2020; Saks and Landsman 2020). Literature from the US shows that medical civil liability spurs the adoption of "defensive strategies" (i.e., defensive medicine) (Marchisio 2020). Notwithstanding Canada's low rates and low success rates - of medical malpractice litigation (Flood and Thomas 2011), the stress 
and fear of a complaint or lawsuit appears to cause some physicians to practise defensive medicine by overprescribing tests, procedures and treatments (Nash et al. 2004). Indeed, a US study found that medical students are exposed to malpractice concerns and taught considerable defensive medicine from faculty at an early stage (Johnston et al. 2014). Although estimates of the costs of defensive medicine are scarce in Canada, evidence suggests that such practices do influence physician activity, with studies finding that some Canadian physicians feel the need to practise defensive medicine (Smith et al. 2016). Research from the US suggests that defensive medicine costs account for anywhere from $2 \%$ to $10 \%$ of the total national healthcare bill (Antoci et al. 2016). Cunningham and Dovey (2006) showed that nofault systems reduced medicolegal pressure on physicians and resulted in cost savings.

A converse concern is that shifting to a no-fault system will lead physicians to undervalue patient safety. Without the deterrent threat of medical malpractice litigation, physicians may encourage shortcuts to enhance speed and increase income. This concern, however, was not borne out in the evaluation of New Zealand's no-fault system (Wallis 2013). Moreover, some authors have suggested that the current system creates barriers to reporting of error but a no-fault scheme may increase reporting and improve care through transparency and education (Studdert and Brennan 2001b).

\section{Is a no-fault system right for Canada?}

By using the 2017 CMPA budget of $\$ 662$ million and upper limit estimates of $18 \%$ for administrative costs, a no-fault system in Canada could cost up to $\$ 119$ million to administer and result in at least $\$ 543$ million awarded directly to patients compared to the $\$ 250$ million awarded in 2017 in the current system. Armstrong and Tess (2008) also found that claimants have better health outcomes in no-fault systems due to the shorter times to compensation, which leads to faster access to treatment and a focus on rehabilitation and return to work. In Canada, many rehabilitation services (i.e., physical, occupational and speech therapy-related) are outside the purview of the publicly paid healthcare system. In their evaluation, no-fault schemes come out ahead, with an increased portion of claimants covered, improved claimant outcomes, an increased portion of costs going directly to claimants, a more equitable distribution of claimant outcomes and a similar level of system costs when compared to tort systems (Armstrong and Tess 2008).

\section{The implications of a Canadian no-fault system}

A move from a tort-based to a no-fault compensation system would impact many stakeholders - from physicians and patients in the foreground to funders, such as the CMPA, malpractice litigators and provincial governments in the background. A no-fault system would be more transparent and more equitable for patients, allowing for a greater number of injured patients to be compensated. Physicians would also benefit from such a system, with reduced medicolegal pressures and decreased impetus to practise defensive medicine. 
Governments and the public would benefit from reduced administrative costs in the new system and more funding flowing directly to patients in need. Despite the interests in the legal and insurance communities who understandably will oppose medical malpractice reform, there has been increasing interest from physician groups, patients and governments to consider reform options. Illuminating the financial facts of tort and no-fault systems may help galvanize policy actions. The policy change required may come about at the provincial level, for example, with one provincial government taking the leap required, which may inspire other provinces to follow suit. In such a scenario, the province should proceed to implement a no-fault plan instead of conducting more consultations as there have already been many reports and studies on this topic (Gilmour 2006; Goudge 2017; Pritchard 1990). Such a province may choose to look at the workers' compensation system as an example another no-fault system that was successfully implemented despite opposition from vested interest groups.

Alternatively, a province may choose to implement more drastic measures. For example, as part of their efforts to curb healthcare costs, in early 2020, Alberta's Ministry of Health cancelled their contract with physicians and indicated that they will limit medical liability insurance reimbursement. Although this may reduce the public subsidy for medical liability insurance, it is not a solution that works to provide better compensation to injured patients. It could provoke physicians, however, to advocate for adoption of a no-fault medical malpractice system, which in turn will help shift the political imperative toward action for reform.

\section{Conclusion}

There have been many calls over the years for reform of our medical malpractice system. At stake are serious questions regarding ethics, social justice, equity and efficiency. The lion's share of CMPA funding comes from taxpayers - the patients themselves - and should rightly be used to compensate injured patients instead of paying for legal and administrative costs. The time has come for significant reform of this sector, and we argue that evidence from around the world strongly suggests a Canadian version of a no-fault scheme would benefit physicians and their patients alike and, from a public policy perspective, provide a far better return on investment.

\section{Acknowledgement}

The authors gratefully acknowledge and thank Bryan Thomas, MA, SJD, from the Center for Health Law, Policy and Ethics, University of Ottawa, for research support and assistance, along with MiCare staff Valentina Ly, MLIS, for data collection and research support and Sarah Hutchinson, $\mathrm{PhD}$, for editorial assistance in the preparation of this manuscript. 


\section{Funding}

Although no specific funding has been received for this study, organizational support was provided by the Maternal-Infant Care Research Centre (MiCare) at Mount Sinai Hospital in Toronto, ON. MiCare is supported by a Canadian Institutes of Health Research (CIHR) Team Grant (CTP 87518) and the Ontario Ministry of Health. Rowe's research is supported by a Scientific Directors Operating Grant (SOP 168483) from Canadian Institutes of Health Research and Flood's research programs are supported by a University of Ottawa Research Chair in Health Law and Policy.

Correspondence may be directed to: Shoo K. Lee, Department of Pediatrics, Mount Sinai Hospital, 19-231M, 600 University Avenue, Toronto, ON M5G 1X5. He can be reached by phone at 416-586-4800x6370 and by e-mail at shoo.lee@sinaihealthsystem.ca.

\section{References}

Antoci, A., A.F. Maccioni and P. Russu. 2016. The Ecology of Defensive Medicine and Malpractice Litigation. PLoS ONE 11(3): e0150523. doi:10.1371/journal.pone.0150523.

Armstrong, K. and D. Tess. 2008, November. Fault Versus No Fault - Reviewing the International Evidence Institute of Actuaries of Australia. Retrieved March 29, 2019. <https://actuaries.asn.au/Library/Events/ GIS/2008/GIS08_3d_Paper_Tess,Armstrong_Fault\%20versus\%20No\%20Fault\%20-\%20reviewing\%20 the\%20international\%20evidence.pdf $>$.

Baker, G.R., P.G. Norton, V. Flintoft, R. Blais, A. Brown, J. Cox et al. 2004. The Canadian Adverse Events Study: The Incidence of Adverse Events among Hospital Patients in Canada. CMAJ 170(11): 167886. doi:10.1503/cmaj.1040498.

Barringer, P.J. 2006. Windows of Opportunity: State-Based Ideas for Improving Medical Injury Compensation and Enhancing Patient Safety. Common Good. Retrieved April 20, 2019. <https://vabirthinjury.com/wp-content/ uploads/2015/12/Commongood-brochure-listing-Vabirth.pdf>.

Bismark, M. and R. Paterson. 2006. No-Fault Compensation in New Zealand: Harmonizing Injury Compensation, Provider Accountability, and Patient Safety. Health Affairs 25(1): 278-83. doi.org/10.1377/ hlthaff.25.1.278.

Bovbjerg, R.R., F.A. Sloan and P.J. Rankin. 1997. Administrative Performance of "No-Fault" Compensation for Medical Injury. Law and Contemporary Problems 60(2): 71-115. doi:10.2307/1192220.

Collier, R. 2017. CMA Votes for Review of Medical Liability System. CMAJ 189(36): E1153. doi:10.1503/ cmaj.1095486.

Cunningham, W. and S. Dovey. 2006. Defensive Changes in Medical Practice and the Complaints Process: A Qualitative Study of New Zealand Doctors. New Zealand Medical Journal 119(1244): U2283.

Di Gregorio, V., A.M. Ferriero, M.L. Specchia, S. Capizzi, G. Damiani and W. Ricciardi. 2015. Defensive Medicine in Europe: Which Solutions? European Journal of Public Health 25(Suppl_3): ckv171.043. doi:10.1093/ eurpub/ckv171.043.

Flood, C.M. and B. Thomas. 2011. Canadian Medical Malpractice Law in 2011: Missing the Mark on Patient Safety. Chicago-Kent Law Review 86(3): 1053-92.

Gibson, E. 2016. Is It Time to Adopt a No-Fault Scheme to Compensate Injured Patients? Ottawa Law Review 47(2): 303-38. doi:10.2139/ssrn.2744432.

Gilmour, J.M. 2006. Commissioned Reports and Studies. Patient Safety, Medical Error and Tort Law: An International Comparison. Paper 42. Retrieved March 29, 2019. <https://digitalcommons.osgoode.yorku.ca/cgi/ viewcontent.cgi? referer $=\&$ httpsredir $=1 \&$ article $=1041 \&$ context $=$ reports $>$. 
Gilmour, M. and A. Luft. 2019, September 12. No-Fault Medical Malpractice Insurance? Quebec Doctors Like the Idea. CTV News. Retrieved February 12, 2020.<https://montreal.ctvnews.ca/ no-fault-medical-malpractice-insurance-quebec-doctors-like-the-idea-1.4591187>.

Goudge, S. 2017, December 29. Report to Ontario Ministry of Health and Long Term Care Re: Medical Liability Review. Government of Ontario. Retrieved March 29, 2019. <http://www.health.gov.on.ca/en/common/ ministry/publications/reports/medical_liability/docs/medical_liability_review_en.pdf>.

Horwitz, J. and T.A. Brennan. 1995. No-Fault Compensation for Medical Injury: A Case Study. Health Affairs 14(4): 164-79. doi:10.1377/hlthaff.14.4.164.

Johnston, W.F., R.M. Rodriguez, D. Suarez and J. Fortman. 2014. Study of Medical Students' Malpractice Fear and Defensive Medicine: A “Hidden Curriculum?” Western Journal of Emergency Medicine 15(3): 29398. doi:10.5811/westjem.2013.8.19045.

Marchisio, E. 2020. Medical Civil Liability Without Deterrence: Preliminary Remarks for Future Research. Journal of Civil Law Studies 13(1).

Nash, L., C. Tennant and M. Walton. 2004. The Psychological Impact of Complaints and Negligence Suits on Doctors. Australasian Psychiatry 12(3) 278-81. doi: 10.1080/j.1039-8562.2004.02079.x.

Nosheen, H. and A. Culbert. 2019, April 18. As Fewer Patients Sue Their Doctor, the Rate of Winning Malpractice Suits Is Dropping Too. CBC. Retrieved May 16, 2019. <https://www.cbc.ca/news/health/ medical-malpractice-doctors-lawsuits-canada-1.4913960>.

Ontario Ministry of Health and Long-Term Care. 2016. Chapter 3, Section 3.11: Physician Billing. In 2016 Annual Report of the Office of the Auditor General of Ontario. Retrieved December 18, 2018. $<$ https://www.auditor.on.ca/en/content/annualreports/arreports/en16/v1_311en16.pdf >.

Prichard, J.R.S. 1990. Liability and Compensation in Health Care: A Report to the Conference of Deputy Ministers of Health of the Federal/Provincial/Territorial Review on Liability and Compensation Issues in Health Care. Appendix A, Health Care Liability and Compensation Review - Working Paper. University of Toronto Press.

Saks, M.J. and S. Landsman. 2020. The Paradoxes of Defensive Medicine. Health Matrix: The Journal of LawMedicine 30(1): 25-84. Retrieved April 20, 2020. <https://scholarlycommons.law.case.edu/healthmatrix/vol30/ iss $1 / 4>$.

Shannon v. Canadian Medical Protective Association - 2016 NBQB 004. Retrieved March 28, 2019. <http:// canlii.ca/t/gnh5s $>$.

Sloan, F.A., K. Whetten-Goldstein, E.M. Stout, S.S. Entman and G.B. Hickson. 1998. No-Fault System of Compensation for Obstetric Injury: Winners and Losers. Obstetrics \& Gynecology 91(3): 437-43. doi:10.1016/ s0029-7844(97)00705-9.

Smith, T.R., M.M. Hulou, S.C. Yan, D.J. Cote, B.V. Nahed, M.A. Babu et al. 2016. Defensive Medicine in Neurosurgery: The Canadian Experience. Journal of Neurosurgery 124(5): 1524-30. doi:10.3171/2015.6.JNS15764.

Studdert, D.M., E.J. Thomas, B.I.W. Zbar, J.P. Newhouse, P.C. Weiler, J. Bayuk et al. 1997. Can the United States Afford a "No-Fault" System of Compensation for Medical Injury? Law and Contemporary Problems 60(2): 1-34. doi:10.2307/1192218.

Studdert, D.M. and T.A. Brennan. 2001a. Toward a Workable Model of "No-Fault" Compensation for Medical Injury in the United States. American Journal of Law E Medicine 27(2-3): 225-52.

Studdert D.M. and T.A. Brennan. 2001b. No-Fault Compensation for Medical Injuries: The Prospect for Error Prevention. JAMA 286(2): 217-23. doi:10.1001/jama.286.2.217.

Taylor, P. 2013, April 5. Patients' Odds of Winning Medical Malpractice Suits in Canada Aren't Good, Says New Book. The Globe and Mail. Retrieved November 29, 2019. <https:/www.theglobeandmail.com/life/ health-and-fitness/health-navigator/patients-odds-of-winning-medical-malpractice-suits-in-canada-arent-goodsays-new-book/article10812604/>.

Wallis, K. 2013. New Zealand's 2005 'No Fault' Compensation Reforms and Medical Professional Accountability for Harm. New Zealand Medical Journal 126(1371): 33-44. 
Canada's System of Liability Coverage in the Event of Medical Harm: Is It Time for No-Fault Reform?

World Bank. 2013. Medical Malpractice Systems Around the Globe: Examples from the US-Tort Liability System and the Sweden-No Fault System. Retrieved March 29, 2019. <http://documents.worldbank.org/curated/ en/421621468779085220/pdf/290110English0malpractice1systems.pdf $>$.

HEALTHCARE QUARTERLY・VOL.24 NO.2

\section{RESPONDING TO THE COVID-19 PANDEMIC}

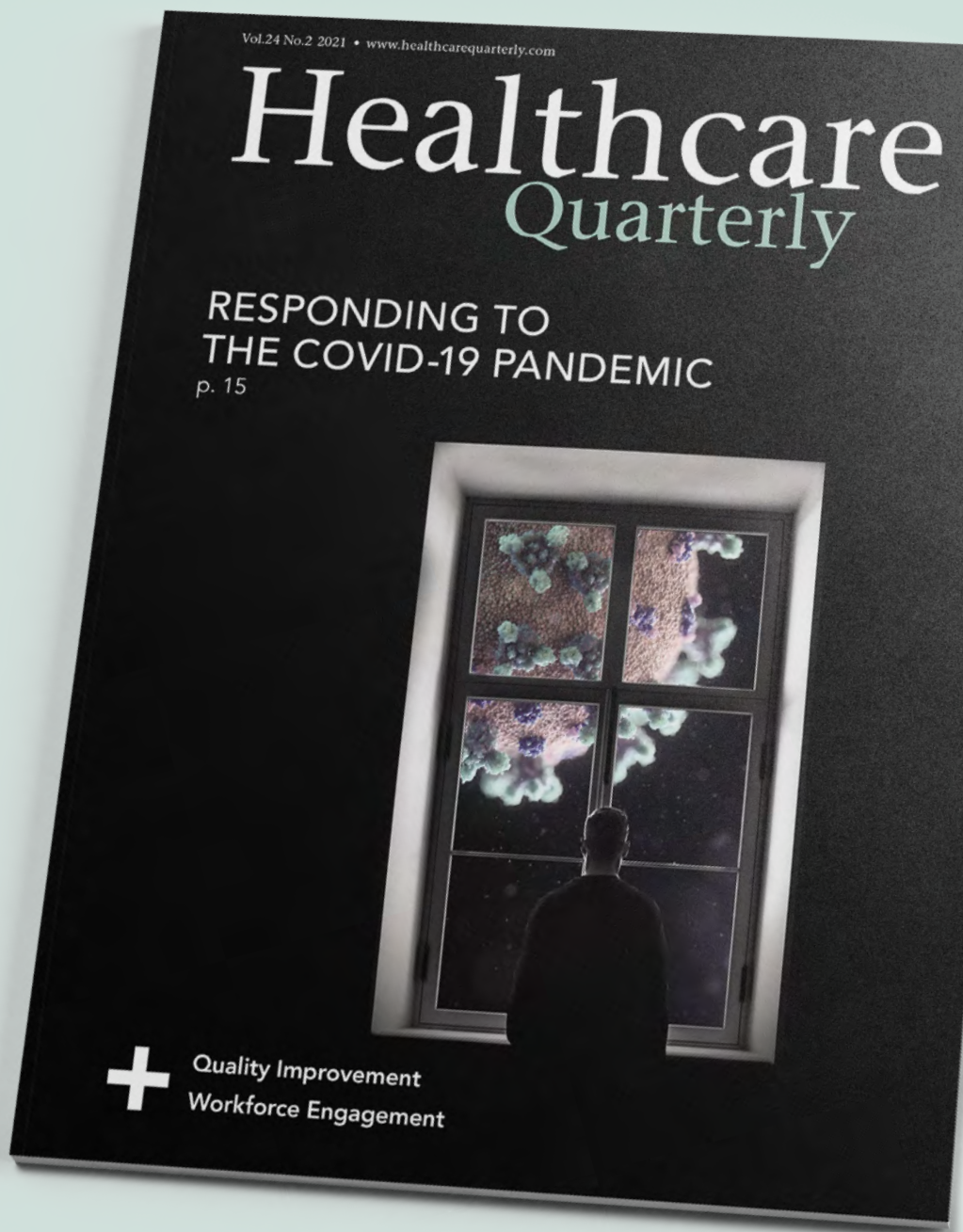

\section{AVAILABLE FROM LONGWOODS HEALTHCAREQUARTERLY.COM}

